\title{
Diabetic and Non-diabetic Subjects with Ischemic Stroke: Risk Factors, Stroke Topography and Hospital Outcome
}

MD. MAHFUJ-UL-ANWAR, ${ }^{1}$ SHAH MD. SARWER JAHAN, ${ }^{2}$ SAJEDA AFRIN, ${ }^{3}$ MD. ZAKIR HOSSAIN ${ }^{4}$

\begin{abstract}
:
Background and Purpose: Diabetes and ischemic stroke are common diseases that frequently occurring together. Several studies have shown that people with diabetes have approximately twice the risk of ischemic stroke compared with those without diabetes.Although diabetes is a strong risk factor for ischemic stroke, it is still unclear whether risk factors, neuroimaging findings and hospital outcome are different in diabetic and nondiabetic patients. The aim of the present study was to evaluate cerebrovascular risk factor prevalence, neuroimaging findings and hospital outcome in patients between diabetic and non-diabetic of ischaemic stroke.

Methods:We conducted a prospective study of 380 consecutive patients with cerebral infarction admitted into Rangpur Medical College Hospital over a 18-month period. With the use of a simple identical data sheet, we recorded the demographics, cardiovascular risk factors, neuroimaging findings and outcome in ischemic stroke patients with and without diabetes.

Results: Overall, diabetes was present in 76 patients (20\%). Diabetic patients, compared with those without diabetes, were younger $(p=.034)$ and they were more likely to have hypertension (69.7\%), hyperlipidemia (28.9\%), ischemic heart disease (22.4\%), previous cerebral infract (23.7\%) and renal impairment (19.7\%). Diabetic infract more frequently occurred in thalamus (II.8\%), pons (9.2\%) and with cerebral posterior involvement (13.2\%). Mortality was higher in diabetic group $(P=.046)$.

Conclusions: Diabetic patients had higher risk burden for ischemic stroke with poorer short term hospital outcome than non-diabetic subjects. So control of diabetes and other risk factors along with a strict observation of adult individuals' healthy life-style should warrant successful ischemic stroke prevention in our country.
\end{abstract}

Key Words: Ischemic stroke, diabetes mellitus, risk factors, stroke topography, hospital outcome.

\section{Introduction:}

Stroke and diabetes mellitus (DM) are two of the leading causes of death worldwide. The prevalence of stroke in adult patients with DM is high and the risk of death is about twice that of people of similar age without DM. ${ }^{1}$ In the largest case control study with adjustment for multiple known risk factors,${ }^{2}$ the risk of stroke for diabetic individuals increased by 2.3. Two other large studies ${ }^{3,4}$ reported similar findings with odds ratios (OR) of 2.12 and 2.47. The combination of stroke and DM is associated with worse stroke-related outcome, high disability and stroke recurrence. ${ }^{5,6}$ Approximately $20 \%$ of patients with DM die from stroke. ${ }^{7}$

1. Medical officer, Department of Medicine, Rangpur Medical College (RpMC), Rangpur, Bangladesh.

2. Associate professor, Department of Medicine, RpMC, Rangpur,Bangladesh.

3. Lecturer, Department of Physiology, RpMC, Rangpur Bangladesh.

4. Professor and Head, Department of Medicine, RpMC, Rangpur, Bangladesh.

Corresponding author: Md. Mahfuj-Ul-Anwar, Medical officer, Department of Medicine, RpMC, Rangpur, Bangladesh.
Diabetes mellitus is a well-established independent risk factor for ischemic stroke. ${ }^{8-11}$ Other studies ${ }^{12-14}$ have established that the association between DM and stroke is related to the pathologic changes observed in brain vessels. As diabetic angiopathy is presumed to differ from atherosclerotic angiopathy, strokes experienced by diabetic versus non-diabetic individuals may also differ. On this basis the aims of this study were:

1. To evaluate cerebrovascular risk factor prevalence in diabetic stroke patients in comparison with non-diabetic.

2. To determine the stroke topography and hospital outcome difference between diabetic and non-diabetic ischemic stroke.

\section{Materials and Methods:}

Study population:

This study was performed among the patients admitted into Department of Medicine, Rangpur medical college hospital, Rangpur from January 2010 to June 2011 with the clinical features and CT scan findings of stroke. 380 patients with cerebral infarction was selected by purposive sampling. 


\section{Materials and Methods}

This study included 380 patients with acute ischemic stroke diagnosed by history, clinical findings and confirmed by CT scan of brain within 1 week of attack. At enrollment patient's socio-demographic characterictics, risk factors for stroke and clinical presentations were recorded. All patients were investigated with routine investigations and CT scan of brain. Treatment was given accordingly and inpatient outcome were observed.

Hypertension was diagnosed when the blood pressure measured in the hospital was $>140 / 90 \mathrm{mmHg}$ or if the patient was taking antihypertensive agents. Diabetes was diagnosed if a patient was using oral hypoglycemic agents or insulin and/ or post-stroke repeated fasting plasma glucose levels $\geq 7.0 \mathrm{mmol} / \mathrm{L}(\geq 126 \mathrm{mg} / \mathrm{dL})$ and 2 hours after glucose level $\geq 11.1 \mathrm{mmol} / \mathrm{L}(\geq 200 \mathrm{mg} / \mathrm{dl})$ and /or the glycosylated hemoglobin level exceeded 6.5\%. Hyperlipidemia was diagnosed if a patient was taking lipid lowering drugs and / or serum total cholesterol $\geq 200 \mathrm{mg} / \mathrm{dl}$ or serum triglyceride $\geq$ $150 \mathrm{mg} / \mathrm{dl}$ or serum LDL cholesterol $\geq 130 \mathrm{mg} / \mathrm{dl}$ or serum HDL cholesterol $<40 \mathrm{mg} / \mathrm{dl}$. Sedentary workers were those who worked setted most of the time (teachers, office staffs, bank employees, unemployed and retired persons with no or little movement). Housewife, students, sales representatives, technical workers and NGO field workers were considered as mild to moderate workers. Day laborers, rickshaw pullers and farmers were considered as heavy workers.

All relevant informations were recorded in a predesigned questionnaire. Collected data were compiled and appropriate analyses were carried out using computer based software, Statistical Package for Social Science (SPSS). Statistical significance was set at $\mathrm{P}<0.05$.

\section{Result:}

Among the 380 ischemic stroke patients, 76(20\%) patients were diabetic. Table- I showed that the diabetic stroke patient was 2.95 years younger than the nondiabetic stroke patient $(61.71 \pm 10.090$ versus $64.66 \pm 11.028, \mathrm{p}=.034)$ and diabetic stroke was less frequent above the age of 80 years. Male: female ratio in diabetic and nondiabetic groups was 1:0.49 and 1:0.53 respectively (Table-II). On the basis of socioeconomic status (Table-III) the middle-class comprised the majority in diabetic and non-diabetic group $(78.9 \%$ versus $73.4 \%, \mathrm{p}=.358$ ). Diabetic patients more frequently had hypertension (69.7\%), hyperlipidemia (28.9\%), ischemic heart disease (22.4\%), previous cerebral infract (23.7\%) and renal impairment (19.7\%). However, valvular heart disease $(5.3 \%$ versus $14.1 \%, \mathrm{p}=.035)$ and atrial fibrillation $(3.9 \%$ versus $11.5 \%, \mathrm{p}=.049$ ) was less frequent in the diabetic group (Table IV). Table V showed the site of the infract in both groups. Diabetic infract more frequently occurred in thalamus $(11.8 \%)$, pons $(9.2 \%)$ and cerebral posterior involvement (13.2\%). On the other hand, they were less frequently involved the parietal $(19.7 \%$ versus $31.9 \%, \mathrm{P}=$ $.037)$ and temporal lobe (23.7\% versus $36.5 \%, \mathrm{P}=.035)$. In-hospital outcome, mortality was higher in diabetic patients ( $21.1 \%$ versus $12.2 \%, \mathrm{P}=.046)$ (Table-VI).

Table-I

Age of the study subjects

\begin{tabular}{lccc}
\hline $\begin{array}{l}\text { Age group } \\
\text { (years) }\end{array}$ & $\begin{array}{c}\text { Diabetic } \\
(\mathrm{n}=76)\end{array}$ & $\begin{array}{c}\text { Non-diabetic } \\
(\mathrm{n}=304)\end{array}$ & $\begin{array}{c}\mathrm{P} \\
\text { value }\end{array}$ \\
\hline $41-50$ & $7(9.2 \%)$ & $27(8.9 \%)$ & .928 \\
$51-60$ & $31(40.8 \%)$ & $95(31.3 \%)$ & .114 \\
$61-70$ & $21(27.6 \%)$ & $101(33.2 \%)$ & .350 \\
$71-80$ & $12(15.8 \%)$ & $34(11.2 \%)$ & .271 \\
Above 80 & $5(6.6 \%)$ & $47(15.5 \%)$ & $.044 *$ \\
Mean \pm SD & $61.71 \pm 10.090$ & $64.66 \pm 11.028$ & $.034 *$ \\
\hline
\end{tabular}

$* \mathrm{P}=<0.05$ is significance.

Table-II

Sex distribution of the study subjects

\begin{tabular}{lccc}
\hline Sex & $\begin{array}{c}\text { Diabetic } \\
(\mathrm{n}=76)\end{array}$ & $\begin{array}{c}\text { Non-diabetic } \\
(\mathrm{n}=304)\end{array}$ & $\begin{array}{c}\mathrm{P} \\
\text { value }\end{array}$ \\
\hline Male & $51(67.1 \%)$ & $197(64.8 \%)$ & .706 \\
Female & $25(32.9 \%)$ & $107(35.2 \%)$ & \\
\hline
\end{tabular}

Table-III

Economic status of the study subjects

\begin{tabular}{lccc}
\hline $\begin{array}{l}\text { Economic } \\
\text { status }\end{array}$ & $\begin{array}{c}\text { Diabetic } \\
(\mathrm{n}=76)\end{array}$ & $\begin{array}{c}\text { Non-diabetic } \\
(\mathrm{n}=304)\end{array}$ & $\begin{array}{c}\mathrm{P} \\
\text { value }\end{array}$ \\
\hline Lower & $7(9.2 \%)$ & $24(7.9 \%)$ & \\
Middle & $60(78.9 \%)$ & $223(73.4 \%)$ & .358 \\
Upper & $9(11.8 \%)$ & $57(18.8 \%)$ & \\
\hline
\end{tabular}

Table-IV

Risk factors of the study subjects

\begin{tabular}{lccc}
\hline Risk factor & $\begin{array}{c}\text { Diabetic } \\
(\mathrm{n}=76)\end{array}$ & $\begin{array}{c}\text { Non-diabetic } \\
(\mathrm{n}=304)\end{array}$ & $\begin{array}{c}\mathrm{P} \\
\text { value }\end{array}$ \\
\hline Smoking & $48(63.2 \%)$ & $203(66.8 \%)$ & .551 \\
Sedentary life habit & $36(47.4 \%)$ & $130(42.8 \%)$ & .469 \\
Hypertension & $53(69.7 \%)$ & $172(56.6 \% \%)$ & $.037^{*}$ \\
Hyperlipidemia & $22(28.9 \%)$ & $51(16.8 \%)$ & $.016^{*}$ \\
Valvular heart disease & $4(5.3 \%)$ & $43(14.1 \%)$ & $.035^{*}$ \\
Ischemic heart disease & $17(22.4 \%)$ & $38(12.5 \%)$ & $.029^{*}$ \\
Previous cerebral infract $18(23.7 \%)$ & $43(14.1 \%)$ & $.043^{*}$ \\
Renal impairment & $15(19.7 \%)$ & $31(10.2 \%)$ & $.023^{*}$ \\
Atrial Fibrillation & $3(3.9 \%)$ & $35(11.5 \%)$ & $.049^{*}$ \\
\hline
\end{tabular}

$* \mathrm{P}=<0.05$ is significance. 
Table-V

Site of infarction

\begin{tabular}{lccc}
\hline Site & $\begin{array}{c}\text { Diabetic } \\
(\mathrm{n}=76)\end{array}$ & $\begin{array}{c}\text { Non-diabetic } \\
(\mathrm{n}=304)\end{array}$ & $\begin{array}{c}\mathrm{P} \\
\text { value }\end{array}$ \\
\hline Temporal & $18(23.7 \%)$ & $111(36.5 \%)$ & $.035^{*}$ \\
Parietal & $15(19.7 \%)$ & $97(31.9 \%)$ & $.037^{*}$ \\
Internal capsule & $20(26.3 \%)$ & $88(28.9 \%)$ & .649 \\
Thalamus & $9(11.8 \%)$ & $16(5.3 \%)$ & $.039^{*}$ \\
Pons & $7(9.2 \%)$ & $11(3.6 \%)$ & $.040^{*}$ \\
Cerebral posterior & $10(13.2 \%)$ & $19(6.3 \%)$ & $.042^{*}$ \\
involvement & & & \\
\hline
\end{tabular}

$* \mathrm{P}=<0.05$ is significance.

Table-VI

Outcome of the study subjects

\begin{tabular}{lccc}
\hline Outcome & $\begin{array}{c}\text { Diabetic } \\
(\mathrm{n}=76)\end{array}$ & $\begin{array}{c}\text { Non-diabetic } \\
(\mathrm{n}=304)\end{array}$ & $\begin{array}{c}\mathrm{P} \\
\text { value }\end{array}$ \\
\hline Symptom free at discharge & $7(9.2 \%)$ & $41(13.5 \%)$ & .316 \\
In-hospital death & $16(21.1 \%)$ & $37(12.2 \%)$ & $.046^{*}$ \\
\hline
\end{tabular}

$* \mathrm{P}=<0.05$ is significance.

\section{Discussion:}

In our study, prevalence of diabetes was $20 \%$ among the 380 consecutive patients with acute ischemic stroke, similar to that reported in some studies. ${ }^{15-17}$ In other studies, diabetes has been reported to be between $13 \%$ and $36 \% .{ }^{18-20}$ This may be explained by a stronger disposition to stroke in the diabetic patient, because diabetes mellitus is associated with accelerated atherogenesis and also due to the fact that diabetic stroke patients have more often other cerebrovascular risk factors as, in our study, hypertension, hyperlipidemia and ischemic heart disease, previous cerebral infarction which in turn were independent predictors of ischemic stroke in the diabetic population as previously reported by others. ${ }^{17,21-}$ 24

The present study showed that, as observed in other studies, $5,11,15,22,25$ the diabetic patients were younger with less frequently being above 80 years compared with the nondiabetic patient at the onset of stroke. This might be explained by a stronger disposition to stroke in the diabetic patient; apart from their diabetes, they more frequently suffer from other stroke risk factors.

There was no difference between the 2 groups in the sex ratio, consistent with previous studies, ${ }^{5,16-19}$ suggesting that diabetes has the same impact on cerebral vessels in both sexes.
Majority of our patients were from middle class economic condition which also observed in previous hospital based studies. ${ }^{26,27}$

Smoking was distributed equally between the 2 groups same as reported in previous study ${ }^{16}$ but in some studies smoking was less frequent in diabetic group. 5,21

Hypertension was more frequent in diabetic patients, in accordance with previous observations 5,11,15,17,22,24,28,29 emphasizing the fact that diabetes and hypertension are associated. ${ }^{30}$

The present results are consistent with previous studies $5,11,17,22,24$ in which hyperlipidemia was a strong predictor of stroke in diabetes, probably because lipid abnormalities have been shown to be associated with cerebral atherosclerosis. ${ }^{31,32}$

In our study, ischemic heart disease was more frequent in the diabetic population as previously reported by others. ${ }^{17,21,22}$ It could suggest that diabetic patients have concurrent vascular lesions in the heart and the brain due to widespread atherosclerotic disease.

We found previous cerebral infarction as a risk factor for ischemic stroke in diabetic patients which matched with previous study 5,17,21,24 could be due to widespread atherosclerotic effect on both heart and brain.

We observed renal impairment significantly higher in diabetic group same was reported in a study..$^{17}$ Renal dysfunction represents the influence of generalized vascular disease in the kidney. Although renal failure is a very rare primary cause of death in acute stroke, it is a potent predictor of in-hospital mortality in acute ischemic stroke diabetic people. ${ }^{33}$

As in previous studies we observed valvular heart disease ${ }^{17}$ and atrial fibrillation ${ }^{15,16}$ were less frequent in diabetic group compare to nondiabetic patients. Atrial fibrillation may be a cause of more severe handicap by way of motor and cognitive deficits and pseudobulbar syndrome ${ }^{34}$ induced by a higher risk of stroke. ${ }^{35}$

In our study, diabetic infract more frequently occurred in thalamus, pons and cerebral posterior involvement. Similar pattern of brain involvement was reported in previous study. ${ }^{17}$ Diabetes can cause small vessel arteriolopathy, especially in the retina, kidney and brain (mainly in thalamus, internal capsule and pons topography). ${ }^{36,37}$ In a classical autopsy study of cerebrovascular accident in diabetes mellitus, observers ${ }^{14}$ found that small vessel cerebral disease was present about 2.5 times more frequent in diabetes.

Our study showed in-hospital mortality was higher in diabetic patients. An increase in short-term mortality from ischemic 


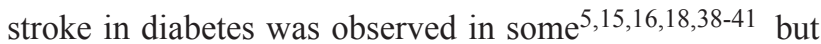
not all studies. ${ }^{17,21,22,42}$ Diabetes increased stroke mortality independent of other factors such as initial stroke severity and ischemic heart disease. ${ }^{15}$

\section{Conclusion:}

Our study shows that the risk factor burden, other than diabetes mellitus, is especially high among patients with DM and cerebral infarction along with poorer short-term hospital outcome. This underlines the need for aggressive secondary preventive treatment among patients with diabetes mellitus. Physical activity, low fat, low carbohydrate diet, weight loss, smoking cessation, moderation of alcohol, careful monitoring of diabetes, hypertension and others risk factors will reduce the occurrence of ischemic stroke and improve quality of life in patients with diabetes.

\section{Conflict of interest: None.}

\section{References:}

1. Centers for Disease Control and Prevention. National diabetes fact sheet: national estimates and general information on diabetes and prediabetes in the United States, 2011. Atlanta, GA: U.S. Department of Health and Human Services, Centers for Disease Control and Prevention, 2011.

2. Jamrozik K, Boradhurst RJ, Anderson CS, Stewart-Wynne EG. The role of lifestyle factors in the etiology of stroke. A population-based case-control study in Perth, Western Australia. Stroke. 1994;25:51-9.

3. Giles WH, Kitter SJ, Hebel JR, Losonczy KG, Sherwin RW. Determinants of black-white differences in the risk of cerebral infarction. Arch Intern Med. 1995;155:1319-24.

4. Manolio TA, Kronmal RA, Burke GL, O'Leary DH, Price TR. Short-term predictors of incident stroke in older adults. Stroke. 1996;27:1479-86.

5. Reeves MJ, Vaidya RS, Fonarow GC, Liang L, Smith EE, Matulonis R, et al. Quality of care and outcomes in patients with diabetes hospitalized with ischemic stroke: findings from Get With the Guidelines-Stroke. Stroke. 2010;41:409417.

6. Jia Q, Zhao X, Wang C, Wang Y, Yan Y, Li H, et al. Diabetes and poor outcomes within 6 months after acute ischemic stroke: the China National Stroke Registry. Stroke.2011;42(10): 2758-62.

7. Phipps MS, Jastreboff AM, Furie K, Kernan WN. The diagnosis and management of cerebrovascular disease in diabetes. Current Diabetes Reports. 2012;12(3):314-23.

8. Arboix A, Morcillo C, García-Eroles L, Massons J, Oliveres $\mathrm{M}$, Targa C: Different vascular risk factor profiles in ischemic stroke subtypes. The Sagrat Cor Hospital of Barcelona Stroke Registry. Acta Neurol Scand. 2000;102:264-270.
9. Arabadzhieva D, Kaprelyan A, Georgieva Z, Tsukeva A, Radeva N. Diabetes mellitus as a risk factor for ischemic stroke. Science \& Technologies. 2014;4(1):27-30.

10. WarlowCP. Epidemiology of stroke. Lancet. 1998; 352(Suppl. 1):1-4.

11. Khoury JC, Kleindorfer D, Alwell K, Moomaw CJ, Woo D, Kissela BM, et al. Diabetes mellitus: a risk factor for ischemic stroke in a large biracial population. Stroke. 2013;44(6): 500-4.

12. Abbott RD, Donahue RP, MacMahon SW, Reed DM, Yano K. Diabetes and the risk of stroke: the Honolulu Heart Program. JAMA. 1987;257:949-52.

13. Davis PH, Dambrosia JM, Schoenberg BS, Schoenberg DG, Pritchard DA, Lilienfeld AM, et al. Risk factors for ischemic stroke: a prospective study in Rochester. Minnesota. Ann Neurol. 1987;22:319-27.

14. Alex M, Baron EK, Goldenberg S, Blumenthal HT. An autopsy study of cerebrovascular accident in diabetes mellitus. Circulation. 1962;25:663-73.

15. Jorgensen HS, Nakayama H, Raaschou HO, Olsen TS: Stroke in patients with diabetes. The Copenhagen Stroke Study. Stroke. 1994;25:1977-1984.

16. Megherbi SE, Milan C, Minier D, Couvreur G, Osseby GV, Tilling $\mathrm{K}$ et al. Association between diabetes and stroke subtype on survival and functional outcome 3 months after stroke. Data from the European BIOMED Stroke Project Stroke. 2003;34:688-694.

17. Arboix A, Rivas A, Garcia-Eroles L, de Marcos L, Massons J, Oliveres M. Cerebral infarction in diabetes: clinical pattern, stroke subtypes, and predictors of in-hospital mortality. BMC Neurol. 2005;5:9.

18. Kiers L, Davis SM, Larkins R, Hopper J, Tress B, Rossiter SC, Carlin J, Ratnaike S. Stroke topography and outcome in relation to hyperglycemia and diabetes. J Neurol Neurosurg Psychiatry. 1992;55:263-270.

19. Woo J, Lam CWK, Kay R, Wong AHY, Teoh R, Nicholls MG. The influence of hyperglycemia and diabetes mellitus on immediate and 3 month morbidity and mortality after acute stroke. Arch Neurol. 1990;47:1174-1177.

20. Olsson T, Viitanen M, Asplund K, Eriksson S, Hägg E: Prognosis after stroke in diabetic patients. A controlled prospective study. Diabetologia. 1990;33:244-249.

21. Nacu A, Thomassen L, Fromm A, Bjerkreim AT, Andreassen UW, Naess H. Impact of Diabetes Mellitus on 1867 Acute Ischemic Stroke Patients. A Bergen NORSTROKE Study. Journal of Research in Diabetes. 2015. DOI: 10.5171/ 2015.112104 .

22. Kissela BM, Khoury J, Kleindorfer D, Woo D, Schneider A, Alwell K, Miller R, Ewing I, Moomaw CJ, Szaflarski JP, 
Gebel J, Shukla R, Broderick JP. Epidemiology of ischemic stroke in patients with diabetes: The Greater Cincinnati/ Northern Kentucky Stroke Study. Diabetes Care 2005;28:355-359.

23. Lithner F, Asplund K, Eriksson S, Hägg E, Strand T, Wester PO: Clinical characteristics in diabetic stroke patients. Diabete Metab 1998;14:15-19.

24. Silva-Fernández J, García-Ruiz R, Moreno-Moreno P, García-Ruiz RM, González-Pereira C. Risk factors, aetiology and prognosis in patients with ischaemic stroke and diabetes mellitus. Endocrine Abstracts. 2015:37,EP459. DOI:10.1530/endoabs.37.EP459.

25. Sweileh WM, Zyoud SH, Sawalha AF, Al-Jabi SW, AbuTaha AS. Clinical characteristics, sex differences and inhospital mortality among stroke patients with and without diabetes mellitus. Diabetologia Croatica. 2011;40-2.

26. Alam B, Habib H, Qurashi FA, Badrul H, Haque A, Mohammed QD. Stroke-Evaluation of risk factors. Bangladesh Journal of Neuroscience. 1999;15(1/2):14-18.

27. Bhuiyan MM, Rahman HZ, Islam MR, Ullah AKMA, Haque AKMA. Four years evaluation of stroke patients in stroke clinic. Bangladesh Journal of Neuroscience.2004; 20(2): 5055.

28. Tuttolomondo A, Pinto A, Salemi G, Fernandez P, Ragonese $P$, Savettieri et al. Diabetic and non-diabetic subjects with ischemic stroke: Differences, subtype distribution and outcome. Nutrition, Metabolism \& Cardiovascular Diseases.2008;18:152-157.

29. Pinto A, Tuttolomondo A, Di Raimondo D, Di Sciacca R, Fernandez P, Di Gati M,et al. A case control study between diabetic and non-diabetic subjects with ischemic stroke. Int Angiol. 2007;26(1):26-32.

30. Stearne MR, Palmer SL, Hammersley S, Franklin SL, Spivey RS, Levy JC, Tidy CR, Bell MJ, Steemson J, Barrow BS, Coster R, Waring K, et al. Tight blood pressure control and risk of macrovascular and microvascular complications in type 2 diabetes: UKPDS38. BMJ. 1998; 317: 703-713.
31. Lukovits TG, Mazzone T, Gorelick PB: Diabetes mellitus and cerebrovascular disease. Neuroepidemiology. 1999;18: $1-14$.

32. Bell DSH. Stroke in the diabetic patient. Diabetes Care. 1994;7:213-219.

33. Wannamethee SG, Shaper AG, Perry IJ: Serum creatinine concentration and risk of cardiovascular disease: a possible marker for increased risk of stroke. Stroke.1997;28:557-563.

34. Jorgensen HS, Nakayama H, Reith J, Raaschou HO, Olsen TS. Acute stroke with atrial fibrillation: the Copenhagen Stroke Study. Stroke.1996;10:1765-1769.

35. Lin HJ, Wolf PA, Kelly-Hayes M, Beiser AS, Kase CS, Benjamin EJ,D'Agostino RB. Stroke severity in atrial fibrillation: the Framingham Study. Stroke. 1996;27:17601764.

36. Fisher CM: Lacunar strokes and infarcts: a review. Neurology.1982;32: 871-876.

37. Fisher CM: Lacunar infarcts. A review. Cerebrovasc Dis. 1991,1:311-320.

38. Olsson T, Viitanen M, Asplund K, Eriksson S, Hägg E: Prognosis after stroke in diabetic patients. A controlled prospective study. Diabetologia. 1990;33:244-249.

39. Tuomilehto J, Rastenyte D, Jousilahti P, Sarti C, Vartiainen E. Diabetes mellitus as a risk factor for death from stroke. Prospective study of the middle-aged Finnish population. Stroke. 1996;27:210-215.

40. Oppenheimer SM, Hoffbrand BI, Oswald GA, Yudkin JS. Diabetes mellitus and early mortality after stroke. BMJ. 1985;291:1014-1015.

41. Lefkovits J, Davis SM, Rossiter SC, Kilpatrick CJ, Hopper JL, Green R, Tress BM. Acute stroke outcome: effects of stroke type and risk factors. Aust N Z J Med. 1992;22:3035 .

42. Sprafka JM, Virnig BA, Shahar E, McGovern PG. Trends in diabetes revalence among stroke patients and the effect of diabetes on stroke survival: The Minnesota Heart Survey. Diabet Med. 1994;11:678-684. 